\title{
The Political Ecology of Vladimir Arsen'ev
}

\author{
SERGEY GLEBOV
}

\begin{abstract}
The article describes the life and work of Vladimir Klavdievich Arsen'ev in the context of the development of settler colonial project in the Far East. The article argues that Arsen'ev, a military officer and a self-taught geographer and ethnographer, shared in a political ecology, which combined "defense" of native peoples and the nature of the Russian Far East with racialized views of Chinese and Korean immigrants. This political ecology, in particular, led Arsen'ev to take part in military operations designed to cleanse remote parts of the Ussuri region of the Chinese and to develop administrative proposals on the governance of native peoples, which foreshadowed Soviet projects.
\end{abstract}

Keywords: Chinese in Russia, ethnography, Far East, Koreans in Russia, native peoples of the Russian Far East, political ecology, Russian empire, settler colonialism, Vladimir Klavdievich Arsen'ev.

$\mathrm{V}$

ladimir Klavdievich Arsen'ev (1872-1930) emerged as arguably Russia's most popular writer whose works focused on the native peoples of Siberia and the Far East. His texts created a canonical image of a Siberian native. In Arsen'ev's writings, Dersu Uzala (a native Nanai guide who accompanied Arsen'ev in his travels in the Ussuri region of the Russian Far East) combined ecological sensitivities with a moral compass and became the most recognizable indigenous Siberian. Arsen'ev's prose was light, vivid, and accessible, and his texts drew on a long tradition of adventure literature while claiming the documentary status of travelogues. Still, this canonization was also due to the fact that the Soviet party-state incorporated Arsen'ev into the standard staple of Soviet culture as early as the 1950s. His texts were published and republished. $V$ debriakh Ussuriiskogo kraia (In the Wilds of the Ussuri 
Region) was published at least eleven times by various Soviet publishing houses between 1926 and 1988, while Dersu Uzala became a true blockbuster of Soviet adventure literature, having been published at least forty times between 1923 and 2010. ${ }^{1}$ Arsen'ev's writings often served as canvases for cinematographic production. In 1928, A. A. Litvinov used Arsen'ev's texts to shoot his ethnographic film The Forest People. ${ }^{2}$ In 1961, Soviet director Agasi Babaian produced a popular-scientific film based on Dersu Uzala.

The reception and recuperation of Arsen'ev's legacy happened in several imperial contexts. Arsen'ev's name was catapulted to both pan-Soviet and global fame when Akira Kurosawa was invited to produce a Soviet film based on Arsen'ev's texts, and the resulting picture received the Academy Award for the best foreign film in 1976. The invitation was a direct result of Cold War relations. Following the Sino-Soviet split, the military encounters on the border in 1968, and China's rapprochement with the United States early in the 1970s, the USSR sought to warm its relations with Japan. With the script produced by the Soviet literary grandee Yuri Nagibin and with Arsen'ev played by the popular Yuri Solomin, Kurosawa's film fit into the growing interest in and aesthetic rehabilitation of the imperial past. In 1975, Solomin had played Ivan Telegin in the popular TV series The Road to Calvary, based on Aleksei Tolstoy's famous novel. Telegin, a tsarist officer, recognizes the correctness of the Bolshevik position and becomes a Soviet commander. The novel was one of the manifestos of the Changing Landmarks ideology, the notion that the former classes had to reconsider their position and cooperate with the Bolsheviks as the rulers of national Russia. The image of an elegant, well-spoken imperial officer became popular in the Soviet cinematography of the 1970s, and Kurosawa's presentation of Arsen'ev, unwillingly and likely unknowingly, contributed to this partial rehabilitation of the imperial past in its Russian national clothes. When Kurosawa's film was released, it did not just captivate Soviet audiences but also left an indelible impression on George Lucas, who based the character of Yoda in his Star Wars series on the image of Dersu Uzala, played by Maksim Munzuk in Kurosawa's film. ${ }^{3}$

Arsen'ev's incorporation into the Soviet canon required significant editing and censoring. If not his prerevolutionary background in the imperial army, then his service in 1911-1915 in the Resettlement Administration, the main colonial agency in Russia, had to be bracketed and qualified. Furthermore, many of his views on human diversity had to be censored in order to fit in with the Soviet ideological sensibilities. 
As a result, the complex figure of Arsen'ev, who had combined fervent nationalism with progressivism but also with elements of European racializing views, was reduced to what a Soviet cinema censor called (probably citing Maksim Gorky's letter to Arsen'ev decades earlier) "our own [Alfred] Brehm and [James] Fennimore Cooper in one person." ${ }^{\prime 4}$ Arsen'ev became a writer of adventure literature and purveyor of ecological sensibilities of the late Soviet era, his legacy largely purified of its imperial context.

In this article, I discuss what I call the political ecology of V. K. Arsen'ev. The term "political ecology" is derived from environmental sciences, where scholars use it to refer to the relationships between society and the natural world. ${ }^{5} \mathrm{I}$ use the term somewhat differently in order to draw attention to the ways in which explorations of nature and ethnography, such as those conducted by V. K. Arsen'ev, were embedded in imperial contexts. I argue that his worldview was shaped by the late imperial juncture and rooted in the experiences and challenges of settler colonialism, nationalizing empire, and revolutionary transformations on the easternmost edges of the Romanov realm. Richard Wortman described the imperial ethos of Russian maritime explorers, and the travelers and administrators in the Far East developed a similar one. ${ }^{6}$ Self-appointed protectors of the national and imperial realm, military officers, explorers, and administrators took it upon themselves to defend both nature and indigenous populations on Russia's Far Eastern frontier, primarily from the alleged predatory exploitation by the Chinese, Koreans, Japanese, and Americans. This defense was combined with military and political considerations and deeply intertwined with interest in the success of settler colonialism in the region. Thus, concerns of these political ecologists included population politics and exploitation of natural resources, economy and geography, Oriental studies, and ethnography. They found a mission and a set of ethical dispositions to make this mission fit in with the rapidly changing imperial contexts. In Arsen'ev's case, he carried this mission across the 1917 divide.

This political ecology does not fit unambiguously into any binary oppositions within which the late imperial period is described. Intelligentsia versus the state, liberals versus conservatives, nationalists versus the imperial traditionalism, peasants versus the landowners, and so forth-all of these oppositions do not reflect the complexity of the imperial situation accurately. In this case, "empire" presents itself more like an "imperial situation": a world in which multiple regimes of difference and categorization coexist. ${ }^{7}$ For example, a person can be at one and the same time a Georgian (a category recognizable in daily 
life and public discourse but not in the legal sense), a nobleman (a civic status enshrined in law), a professional (a social, economic, and cultural status but not reflected in legislation), a member of the revolutionary intelligentsia, an Orthodox person (a legal category that has little to do with one being a practicing Orthodox Christian), a Russian (especially if one resides in an imperial borderland outside of Georgia), and European and white (for instance, in the racialized environment of the early twentieth-century Russian Far East). The imperial state treated all these different categories in different ways and also served as an active producer of new categories of difference. ${ }^{8}$ In the case of Arsen'ev, the imperial bureaucrat was also a member of the progressive public, a writer, an aspiring scholar, a military officer charged with the execution of population politics, and a self-appointed defender of indigenous peoples.

Arsen'ev was born in 1872 in St Petersburg, a son of a minor railroad official and a grandson of a Dutch immigrant and a peasant woman. In 1917, his resume noted that his parents were honorary hereditary citizens, a sub-estate for the elite of the urban dwellers. After a stormy beginning to his schooling and several school expulsions, he joined the army in 1891 as a volunteer and was made a junior officer in 1892. The following year, Arsen'ev enlisted in the 1st St. Petersburg Infantry Juncker School, which he graduated as an officer in 1895. He then served in the Olonetsk and Novocherkassk infantry regiments for five years, mostly garrisoned in the South of European Russia. These five years appear to have been spent in petty bureaucratic activities in the regiments (such as clerking for the regimental court). In 1900, Lieutenant Arsen'ev petitioned to be transferred to the Far East and was assigned to the 1st Infantry regiment of the Vladivostok fortress. On his way to Vladivostok, Arsen'ev had to stop in Blagoveshchensk, where he took part in the suppression of the Boxer rebellion across the river. A little cited document informs us that from July 8 to July 25, 1900, Arsen'ev was "assigned to the detachment of Lieutenant General K. N. Gribskii and took part in action fighting the Chinese out of Sakhalian' [current Heihe across the Amur from Blagoveshchensk, SG]," and in 1902 he was awarded the silver medal "For the Chinese campaign, 1900-1901." This information suggests that Arsen'ev was close to the site of the massacre of the Chinese in Blagoveshchensk in July 1900 and possibly observed it. One cannot but notice a remarkable coincidence in that Arsen'ev's ideal, the famous military explorer N.M. Przheval'skii also had to interrupt his first geographic expedition in 1868 to participate in the suppression of the Chinese rebellion in the Ussuri region. ${ }^{9}$ 
In Vladivostok, Arsen'ev was assigned to lead the educational work of his regiment, as well as to serve on the hunters' command and made his first travels to the interior of the Maritime province. We do not know about his activities during the turmoil of 1905 in Vladivostok, where in July he was appointed commander of the joint battalion of hunting commands of the city. In 1904, Arsen'ev was promoted to shtabs-kapitan rank and awarded the Order of St. Anna 4th degree, and in 1905 the Order of St. Stanislas 3rd degree. These awards reflected the patronage and support of both the military administration of the region during the Russian-Japanese war and of P.F. Unterberger, the general governor of the Priamur krai (1905-1910), who often tasked Arsen'ev with expeditions to explore the less known parts of the province. ${ }^{10}$

In the following two decades, across the two Russian revolutions, the Russo-Japanese-War, and the foreign intervention during the Civil War Arsen'ev would travel tirelessly across the Russian Far East, leading expeditions into the interior of the region, especially into the Sikhote-Alin Mountains. It was on one such expedition that he encountered the Nanai hunter Dersu Uzala, who became his friend and guide. Arsen'ev's expeditions were aimed to produce a particular kind of knowledge about the region: he was a military explorer, and as such, he was charged with identifying weaknesses in defenses, sites of potential enemy intrusions, as well as loyalty and reliability of the populations of the area. As a matter of fact, Arsen'ev was the last in the long line of such explorers of the Russian Far East, all of them military officers: M. Veniukov, N. Przhevalsky, I. Nadarov, and others. A tradition of military geography (understood broadly) emerged in the Russian Far East and markedly colored the production of knowledge about the region's landscape, history, flora and fauna, and populations. ${ }^{11}$

Arsen'ev began to publish reports of his expeditions in the regional press. The most accessible version of these reports is in his book Life and Adventures in the Taiga, which was prepared by the well-known Russian philologist and bibliographer M.K. Azadovsky, albeit in a heavily edited version. ${ }^{12}$ Many of these reports were at a later stage incorporated by Arsen'ev into various books and essays he published. It appears that the first book publication by Arsen'ev was a brochure The Short MilitaryGeographical and Military-Statistical Overview of the Ussuri Region, which was printed in 1912 by the Staff of the Priamur Military District. It was followed by the first ethnographic study by Arsen'ev, Chinese in the Ussuri Region, published by the Priamur branch of the Imperial Geographic Society (and quickly translated into German). Arsen'ev's first publications on the native peoples of the region began to appear in 
1913, when his report to the First Congress of the Physicians of Priamur region on the dying out of the indigenous population appeared in the proceedings. In 1916, Arsen'ev's lectures in Harbin on the same subject were published in local periodicals. Following the war and revolution, the early 1920s saw the publication of several popular stories, including Dersu Uzala in 1923, which attracted the attention of literary figures such as Maksim Gorky and Mikhail Prishvin, and ultimately brought the author fame and recognition.

Arsen'ev's career as a writer and explorer was closely intertwined with the ups and downs of the colonial project in the Far East. Arsen'ev arrived in the Far East at a crucial point. The Boxer Rebellion and the campaign in Manchuria in 1899-1900 marked the onset of the violent stage of imperialism on the Russian-Chinese frontier. Beginning in the 1880 s, settler colonialism started to increase as well. In the early 1880 s, settlers began to arrive in the Far East by circumnavigation from Odessa. In 1898, Russia received the rights to build the railroad through the Qing Manchuria. Colonization in the Maritime province and Manchuria sped up, with Vladivostok and Harbin emerging as the most important centers on the Trans-Siberian Railway. In 1899, Nicholas II established the Kvantun (Kwantung, Guandong) oblast on the Liaodong Peninsula. The Boxer Rebellion provided the Western powers an excuse to invade China, with the Russian army in Manchuria outnumbering the combined armies of the other great powers. Russia seemed to have acquired a permanent footing on Chinese territory, and in 1903 Nicholas II established the viceroyal post for the Far East (the viceroy supervised Manchuria and the Russian Priamur krai). After the suppression of the rebellion and due to the Russian reluctance to leave Manchuria, tensions with Japan began to build up. The breakout of the Russo-Japanese war over interests in Manchuria and Korea was accompanied by the Russian revolution of 1905, with events in Vladivostok turning violent in the summer of 1905. The Portsmouth Treaty deprived Russia of the Kvantun province and the Southern Manchurian Railroad, although Harbin and the Chinese Eastern Railway remained under Russian control..$^{13}$

The explosion of violence in the Far East during the first Russian Revolution ended by 1907. P. A. Stolypin's government embarked on a massive campaign to resolve the social ills of the empire by encouraging mass resettlement of peasants in the east. Millions of peasants began to arrive in Siberia and the Far East. The Priamur krai saw the influx of almost 200.000 settlers in just four years, 1906-1910, and the Russian authorities prepared over 200,000 land allotments for further settlement. ${ }^{14}$ The task of the settlers was to both increase Russia's demo- 
graphic weight in the region and, importantly, to transform the outlying provinces into what the imperial authorities imagined as a part of the Russian national state. In the Far East, and more specifically, in the Maritime province of the Russian empire, that process meant increased conflicts over land and growing tensions about what was now called, in racial terms, "the yellow question." ${ }^{15}$

By that time Arsen'ev emerged as an experienced traveler in the wilderness of the Maritime province. He traveled in the region every year from 1906 to 1915, and his expeditions formed part of the larger effort to map and describe the Far Eastern provinces. From 1906 to 1910, over forty expeditions explored the region. ${ }^{16}$ His exploration of the northern passage across the Ussuri region (along the imaginary line from Khabarovsk to the coast of the Sea of Japan) earned him a reputation among the imperial bureaucrats as a reliable, disciplined, and resourceful officer. He began to develop an interest in ethnography and anthropology and sent collections he gathered on his travels to the Russian Museum in St. Petersburg. In 1909, Arsen'ev met Bruno Adler, an ethnographer from the Russian Museum and a student of Friedrich Ratzel, with whom he kept in touch the next decade. ${ }^{17}$ Around 1910, Arsen'ev established correspondence with D.N. Anuchin, one of the leaders of anthropological research in Russia. He met Lev Shternberg in Khabarovsk in 1910, who was at that time a revolutionary exile, but a decade later became the leading Soviet ethnographer. ${ }^{18}$ The Russian Museum purchased some of Arsen'ev's collections, and his name became known in the ethnographic circles. In 1913, Fridtjof Nansen visited the Russian Far East and produced a celebratory book on Russian settler colonialism beyond the Urals. Nansen met Arsen'ev in Khabarovsk, and later they exchanged letters. ${ }^{19}$ Despite this entrance into academic and museum circles, Arsen'ev remained aware of his limitations as a scholar and his lack of systematic preparation. He did not have a university degree, let alone any specialized training in ethnography. For instance, when he collected skulls of Tungusic peoples in the Far East, he sent them to the Russian Museum and asked Fedor Vovk, an important anthropologist, to perform measurements and calculations and to share the interpreted data with him. ${ }^{20}$ Arsen'ev seemed to orient himself poorly in the contemporary divisions in the Russian anthropological and ethnographic community. Although he was fascinated by the modernity and apparent scientific rationality of racial anthropology, he was drawn more to the anthropogeographic approaches.

In 1910, Arsen'ev was appointed director of the Khabarovsk Museum, a position he combined with continued service. However, his 
career as a military explorer took a new turn with the appointment in 1911 of Nikolai L'vovich Gondatti as the governor general of the Priamur krai. Gondatti, a son of an Italian sculptor and a Russian noblewoman, was to be the first civilian imperial viceroy in the Far East. A graduate of Moscow University, he taught at the Moscow Alexandrovskii Institute. A student and follower of Russia's leading anthropologist, D. N. Anuchin, Gondatti studied the Mansi (a Finno-Ugric people in Western Siberia) and became an expert in Finnish mythology. This work brought him recognition and the job of the secretary of the Imperial Society of Lovers of Natural Science, Anthropology, and Ethnography. The field of ethnography in Siberia at the time was mainly occupied by political exiles turned ethnographers. ${ }^{21}$ Unlike them, in 1894 he agreed to serve as the chief of the district of the Chukotka peninsula, where he earned the reputation as a scholar in Chukchi ethnography and language with international reputation. ${ }^{22} \mathrm{He}$ then served as the head of the Resettlement Administration district in Vladivostok, and as the head of the chancellery of the general governor of Eastern Siberia in Irkutsk, where he witnessed the revolutionary events of 1905. In 1906, as part of Stolypin's influx of new cadres into imperial governance, Gondatti became governor of the Tobol'sk province in Siberia, followed by the governorship of Tomsk province. Following the Russian defeat in the war with Japan, a decision was made to build a railroad on Russian territory to parallel the Chinese Eastern Railroad through Manchuria. The Amur expedition was launched in 1910 to explore the territory of the railroad and became the last large-scale expedition in imperial Russia. Gondatti was appointed its chief and then was immediately promoted to governor general of the Priamur krai in 1911. This was an unusual appointment; until then, the governors general were career military officers. Gondatti presided over the region until the February Revolution of 1917, when he was arrested and sent to St. Petersburg for investigation and later released. Gondatti's mix of scholarly expertise, nationalism, and progressivism made him a recognizable-if not typical—representative of the Stolypin-era administrators. ${ }^{23}$

His scholarly progressivism notwithstanding, Gondatti was one of the most radically anti-Chinese administrators in the Russian Far East. He worked tirelessly to close the Russian labor market in 1910-1911 to Chinese laborers and promoted Russian colonization of the region, all of which aligned with Stolypin's agenda. Gondatti clashed with the aristocratic head of the Resettlement Administration office in Vladivostok, A. A. Tatishchev, over the treatment of Koreans, refusing to follow the latter's suggestions to treat Koreans as regular Russian sub- 
jects. ${ }^{24}$ Scholars noted Gondatti's anti-Jewish policies in the region. ${ }^{25}$ During Gondatti's reign, the Russian Far East's economy grew, along with settler colonization of the region. ${ }^{26}$

After the defeat of the Revolution of 1905, Stolypin's government focused on the creation of the independent farmers' class in Russia, a policy that viewed this class as both a national and a monarchist one. Peasant resettlement and massive colonization of Siberia and the Far East became centerpieces of Stolypin's program. ${ }^{27}$ The Resettlement Administration, established in 1896 as part of the Internal Affairs Ministry, in 1905 was incorporated into the Main Administration of Agriculture and Land Settlement, the central organ of Stolypin's reform. From 1905 to 1915, the Resettlement Administration led by the ambitious G. V. Glinka became a powerful institution in the eastern regions of the empire, controlling an enormous budget, an army of land surveyors, engineers, and doctors, and a network of resettlement offices equipped with hospitals, warehouses, and temporary accommodations for the settlers. ${ }^{28}$ It published its own journal, Voprosy kolonizatsii (Questions of colonization). Able to fight other powerful institutions, like the War Ministry, which controlled the land of the Cossacks, the Resettlement Administration sought to and often did increase and decrease land holdings for entire estates (like Cossacks or peasants). The Resettlement Administration was also a rallying point for progressives, who envisioned its activities as a solution to Russia's social ills. Notably, in 1908-1909, Prince G.E. Lvov, the leader of the united zemstvo organization and the future premier of the Provisional Government, traveled to the Far East to help organize assistance for settlers. ${ }^{29}$

David Macey perceptively noted that Stolypin's era produced "a new generation of enlightened and progressive bureaucrats." ${ }^{\prime 30}$ As the case of Arsen'ev and Gondatti shows, this generation was indeed new, but its progressivism has to be qualified. Their progressivism rested on what I call a vision of the political ecology of the imperial borderland. They took it for granted that Russian settlement and colonization was to bring progress and prosperity to the region. They also saw the situation of the native peoples as demanding protection and support from the "stronger races." At the same time, they agreed on the selective preservation of the natural resources of the region which, in their minds, were exploited in a "predatory" manner, especially by Chinese and Korean immigrants. Thus, as scholars, they saw the study and exploration of the region as a necessary precondition for its development; as imperial administrators, they envisioned themselves as protectors of both the native peoples and the landscape from the destruction inflicted by the 
non-Russian immigrants (in Arsen'ev's case, this was also conducted by Russian settlers to an extent). In this political ecology, support for industrial development, a certain imperial cosmopolitanism, and protection of nature and native peoples coexisted with chauvinist and racist attitudes toward the Chinese and Korean populations. Their political ecology also developed in the moment when nationalizing political imagination reigned and multiple actors-from some parties in the imperial parliament to the dynasty and government-promoted a vision of Russia as a state of Russians.

This political ecology was reflected in the expeditions of 1911-1913, organized by Arsen'ev. In response to complaints by some Russian settlers about the Chinese presence, Gondatti appointed Arsen'ev, now ranked captain, as the special plenipotentiary of the Resettlement Administration and solicited from him a project for his expeditions to sort out the problems in the Ussuri region. Arsen'ev was transferred from the military command to the civilian administration and became an official of the Resettlement Administration, the institution at the center of the colonial project in the Far East. Arsen'ev submitted several proposals under the title "Expeditions to the sea coast to undertake measures to arrest and deport those Chinese without residence permits, suspicious, or otherwise displaying animosity towards the Russian settlers." ${ }^{31}$ Arsen'ev also submitted a map, carefully drawn by his hand, under the title "Schematic designation of the localities, from which it is suggested to remove the troublesome and harmful Chinese element through systematic punitive (karatel'nye) expeditions" (see Figure 1). ${ }^{32}$ English translation does not accurately convey the striking language used by Arsen'ev. The adjective karatel'nyi in 1911 was still a fairly rare word to see in administrative correspondence. It came into active use during the revolution of 1905 when military action to pacify different areas of the empire were described as "punitive." For instance, in 1905, the term was used to describe General von Rennenkampf's campaign to pacify the revolutionary uprisings in the Transbaikal province. It was an innovative use of language to describe organized state violence.

Arsen'ev's "punitive expeditions" (karatel'nye ekspeditsii) continued every summer from 1911 to 1913, resulting in the removal of hundreds of Chinese and the destruction of their houses. ${ }^{33}$ Gondatti issued an instruction to Arsen'ev, which required him to travel from Vladivostok along the coast of the Japanese sea and into the interior of the region along the river valleys. Arsen'ev was to be accompanied by fifteen soldiers. His task was to identify, arrest, and deport any Chinese who had no residence permit and displayed animosity to Russian settlers 


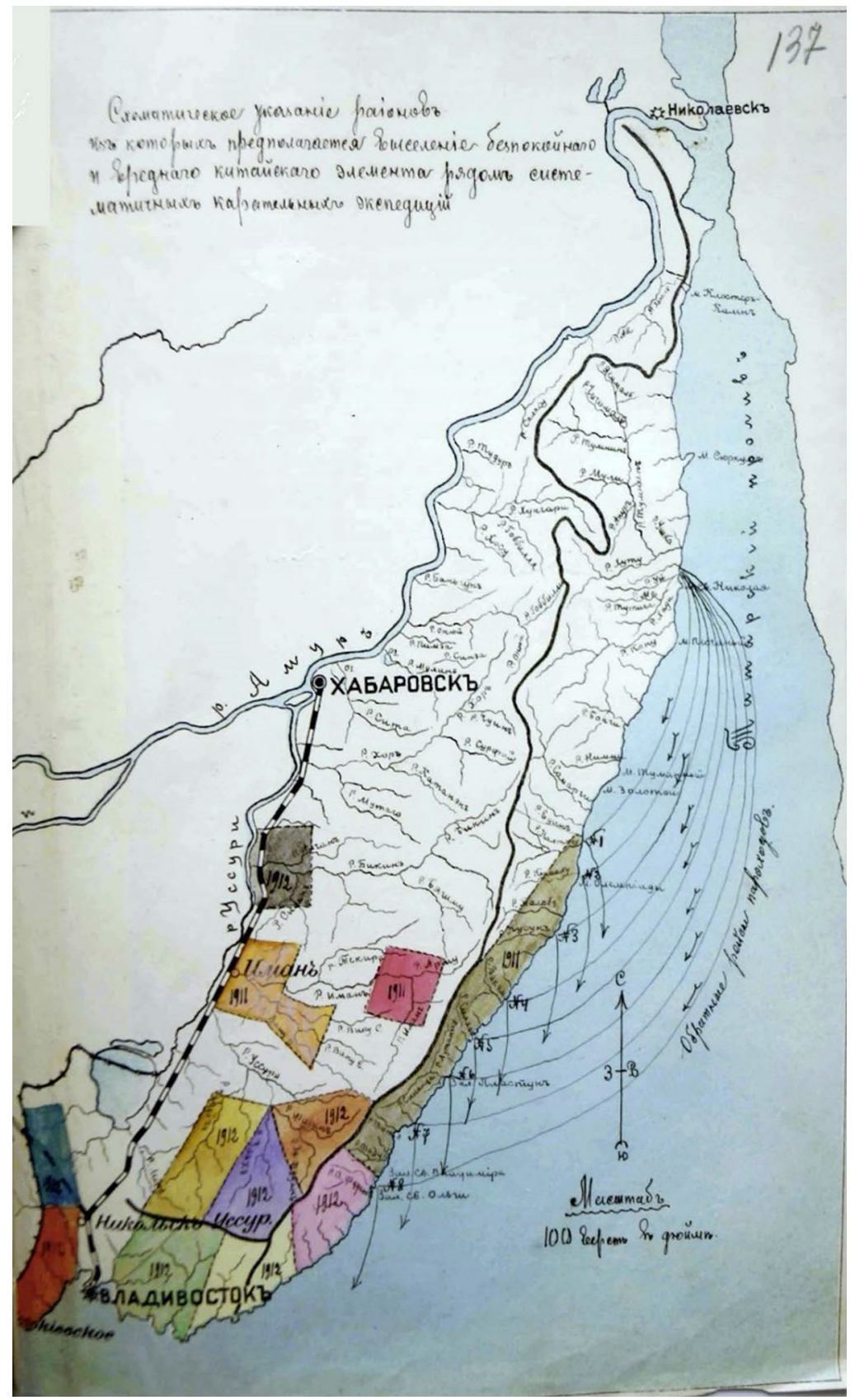

Figure 1. Arsen'ev's map of planned deportations, color-coding regions with the Chinese population. RGIA DV, F. 702, Op. 1, D. 716, L. 137. 
or administration. Arsen'ev was also to separate the Chinese from the Taz (an indigenous group of hybrid Chinese, Nanai, and Udege origin), and provide the latter with official certificates confirming their status as natives and Russian subjects. Any fanza $a^{34}$ built in the region by a Chinese subject to arrest was to be confiscated; if there was no nearby Russian village that could be entrusted with the property, it was to be burned. All weapons and food supplies were to be confiscated, and if transportation proved difficult, destroyed. The arrested Chinese were to be brought to the points of embarkation on the coast, where steamers would take them to Vladivostok and then Chifu (Yantai) on the Shandong Peninsula. Arsen'ev was to keep a travel journal and report to Gondatti on the course of the expedition. Remarkably, Gondatti instructed Arsen'ev to create and maintain a secret network of rural informants, with the provision of special funds to pay for it. The operation was to be kept secret in order to prevent the Chinese from learning about it in advance and fleeing into the Sikhote-Alin Mountains. ${ }^{35}$

From a series of reports submitted by Arsen'ev, we can glean some of the problems he encountered on his mission. For one, many Chinese simply left when they learned about his approach. People shared information about the expedition, and it appears most Russian settlers were not that eager to part with the benefits of having the Chinese settlers as neighbors, trading partners, or workers. On several occasions, Arsen'ev lamented lack of support by Russian peasants and merchants who, he claimed, were economically dependent on the Chinese. The logistics also proved taxing. On one occasion, the expedition pursued a small group of fleeing Chinese for five days in the Ussuri taiga, taking the arrested people to the coast, and guarding them all the time. Arsen'ev struggled with logistical issues and tried to solve them through various "modernizing techniques." On one occasion, he reported to Gondatti that he took along a police dog, which he wanted to train to pursue the fleeing Chinese. ${ }^{36}$ Minimal resources dedicated by imperial authorities to these expeditions served as the main limit on Arsen'ev's own enthusiasm for deportations and arrests, his growing frustration resulting in more and more sweeping proposals to Governor General Gondatti.

As he pursued his expeditions, Arsen'ev grew disenchanted with the local Russian peasants, whom he saw as lazy, disorganized, and losing the competition with the Chinese. Reflecting common anxiety about the qualities of Russians as colonizers, Arsen'ev saw the problem with Russian peasants in how they were "spoiled" by the presence of inexpensive Chinese and Korean labor and reported that many Russian fields were worked by Chinese and Koreans, as well as used to grow 
opium. ${ }^{37}$ "As a matter of fact," Arsen'ev wrote, "the Chinese preoccupy themselves with work on the land, whereas our peasants are satisfied to receive rent from them in the amount of 15 rubles per desiatina." He saw the Chinese as the real owners of the land and lamented that

\begin{abstract}
All of this becomes clear if we take into account the drastic contrast between the Chinese and our settlers: solidarity and mutual support among the former, and internecine conflicts, theft, and cheating among the latter; literacy and sobriety among the Chinese, and drunkenness along with absolute ignorance among the Russians; hard work ethics, persistence, and lack of holidays among the yellow population, and laziness and baseless expectation of handouts from the treasury among the Russians.
\end{abstract}

Thus frustrated by the lack of support by the Russian peasants and their general "underperformance" as settlers, Arsen'ev wrote to Gondatti that the solution should be in the complete and total prohibition for the Chinese to settle in the rural areas of the region. Drawing on the established trope of comparing the Chinese to Jews in the Far East, Arsen'ev suggested a policy of segregation practiced in the Western borderlands: "There does exist the Pale of Settlement for the Jews, and they are deported from the localities beyond it if they cross it. Why can't we established a similar regulation for the 'yellow race'?" Paradoxically, Arsen'ev blamed the Chinese for his frustration with the inability of the Russian peasants to perform as colonizing Kulturträgers: “The absence of Chinese will force Russian peasants to throw away their laziness and get back to work again." ${ }^{38}$

In his reports to Gondatti, Arsen'ev presented the outcome of his expeditions in a dry, statistical fashion. Each report contained the numbers of people deported, houses burnt, and hunting and fishing equipment destroyed. In one report, for instance, Arsen'ev claimed that his expedition arrested and deported over a hundred Chinese individuals, burnt twelve fanzas, and destroyed over six thousand pieces of hunting equipment. Arsen'ev's reports were accompanied by hand-drawn maps, indicating Chinese settlements and fanzas already discovered and burnt (see Figure 2).

Arsen'ev's expeditions to cleanse the rural areas of the Maritime province from the Chinese would have remained an episodic development had they not represented a coherent even if the small-scale culmination of the political ecology. In the absence of a political language capable of articulating how a political community with diverse constituents could look like, both Arsen'ev and Gondatti resorted to 


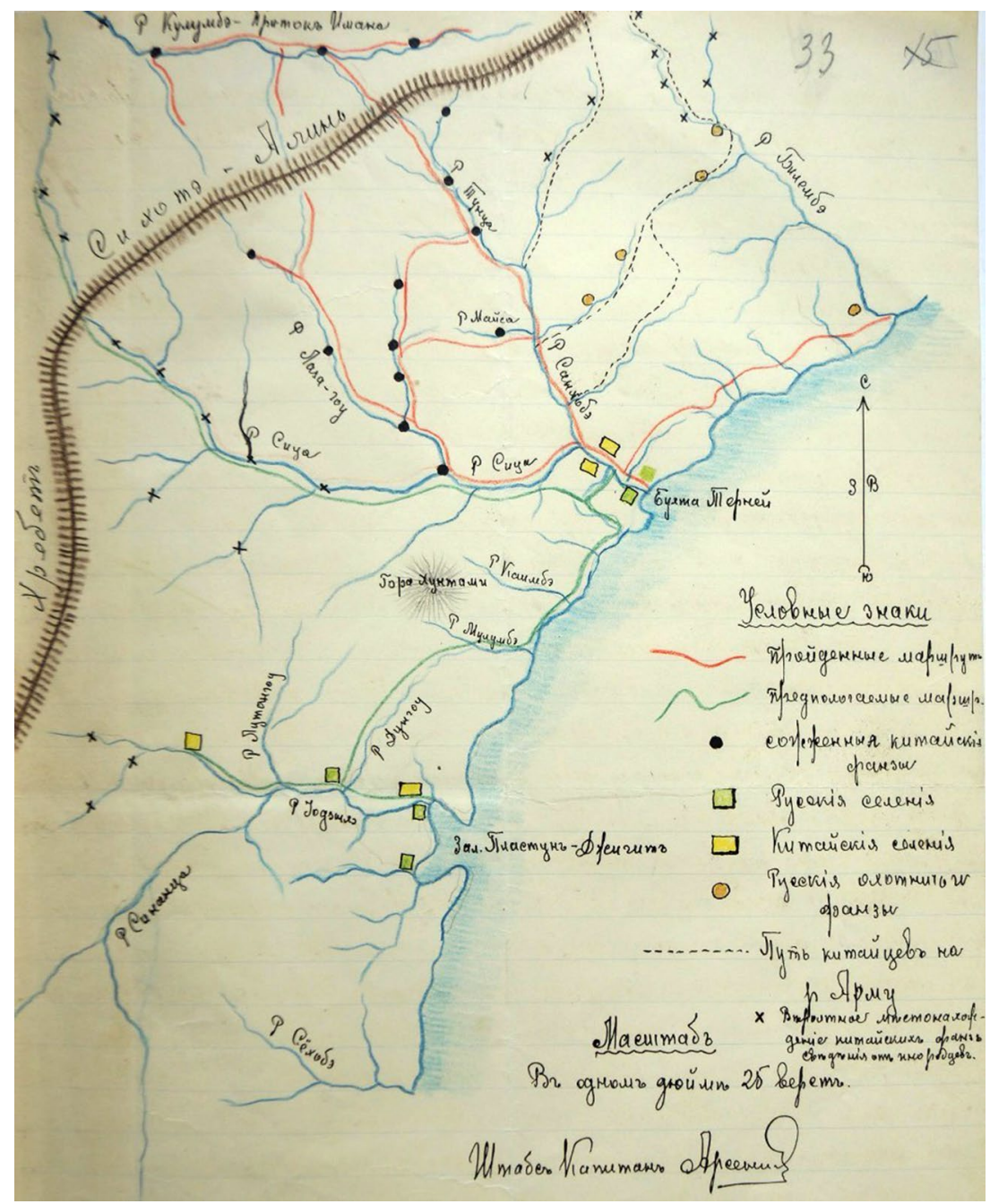

Figure 2. Map of the completed expedition by Arsen'ev in the summer of 1911. Yellow color indicates Chinese and green Russian settlements; black dotes indicate Chinese fanzas burnt by the expedition and crosses potential localities of Chinese fanzas. 
ethnic cleansing — admittedly, on a minor scale—to pursue their vision of progressivism married with settler colonialism. It was in these expeditions that Arsen'ev's views of the Chinese were developed. He came to believe that the Chinese self-organization in the valleys of the rivers of the Ussuri region was a sign of their extraordinary discipline and commitment to anti-Russian causes. The Chinese openly infringed on Russian sovereignty and were governed by their own laws. They engaged in cruel punishments, including burying people alive on Russian territory. He generalized about the Chinese character and suggested that "the Chinese are by nature an extremely cruel people. All their thoughts are focused on how to bring some sort of suffering to a living creature." ${ }^{\prime \prime 9}$ He saw little difference between ordinary Chinese and the famous khunkhuzy - the bandits who terrorized the region of Manchuria and Russian Far East even if he explained that the support provided by ordinary Chinese to the khunkhuzy was motivated by the fear of revenge. Many pages of Arsen'ev's writings were dedicated to the descriptions of how the Chinese exploited and enslaved the indigenous peoples of the area. The Chinese presented a direct challenge to Russian sovereignty: in his view, "it would be mistaken to think that we possess the Ussuri region in an economic sense. We only possess it along the Amur, the narrow line along the railroad, and along the coast. The rest is in Chinese hands." ${ }^{\prime 40}$

Arsen'ev came to view the Chinese in essentialist and racialized terms, but his attitude to the indigenous peoples of the Russian Far East had a different bent. Arsen'ev was not just an aspiring ethnographer; he clearly saw himself as the protector of the weak and endangered peoples. Curiously, later in life, he wrote to one of his friends that his favorite story was Rudyard Kipling's "The Miracle of Purun Bhagat." In Kipling's story, Purun Dass is a Brahmin who succeeds brilliantly in acquiring Western knowledge and in helping his raja to run the kingdom. One day, though, Purun Dass leaves the world of the kingdom and goes to live as an ascetic in the mountains near a village. He learns to communicate with the natural world and nearly achieves enlightenment when a massive flood starts in the mountains, and he rushes to save the people of the village in the valley. He succeeds and dies having accomplished the miracle. By the end of his life Arsen'ev associated himself with Purun Dass and claimed that he wanted to leave the brutal and violent world of cities and "go there, to Dersu." "If not for my family," wrote Arsen'ev, "I would have left for my friends, the natives, to never return to the city, just to be as far away as possible from the madmen, from the people who are only thinking about how to inflict more pain 
on each other." ${ }^{\prime 11}$ The world of the Orochi and Udehe came to signify for Arsen'ev the absence of senseless violence associated with the modern way of life; this world had to be protected against the Chinese but also Russian settlers.

One outcome of his expeditions of the 1910s was the development of the project for the Statute on Inorodtsy of the Priamur krai. ${ }^{42}$ Since the Russian acquisition of the region, the native peoples lived in a sort of legal limbo. It was generally assumed that they should be governed along the lines of the Statute on Inorodtsy of 1822, namely, that they should have their separate communal or clan institutions under police supervision, and that they should enjoy access to land. ${ }^{43}$ However, the application of the Statute on Inorodtsy of 1822 was not formalized in the Priamur region, and smaller native peoples continued to lead a semi-independent life in the depths of the Far Eastern taiga. Russian administrators often invoked the indigenous Nanai, Orochi, or Udehe peoples but only to illustrate the harm of the Chinese presence. They argued that Chinese merchants and hunters mercilessly exploited the indigenous people and turned them against the Russians. At the same time, reports circulated about the native peoples being taxed or drafted by the Qing officials, thus making them an object of anxieties about the weakness of Russian sovereignty. In the early twentieth century, the massive influx of settlers pushed the native Orochi and Udehe of the Ussuri region to the north, into the valleys of remote rivers and onto the inhospitable coast of the Sea of Japan.

In 1913, Gondatti and Arsen'ev prepared the draft of the new Statute on the Inorodtsy of the Priamur region. Although the new statute was not formally promulgated because of the beginning of the war and Russia's entrance into "the continuum of crisis," the draft represents a remarkable document. In many ways, it parted with the traditions of imperial governance in Siberia and foreshadowed the developments of the early Soviet era. In the draft, the special status of the Siberian natives was eliminated, and they were equalized in legal and administrative terms with the estate of Russian peasants. Their administration was supposed to be based on the same principles as that of the peasant communes, and their land allotments were to match the peasant ones. However, the draft also envisioned a series of measures that would become the hallmark of the Soviet policies: mobile medical teams to visit native settlements, mobile and boarding schools for native children, mobile exhibitions and instruction on proper and modern methods of gardening, fishing, and home crafts, and missionary activities (replaced with Marxist propaganda in the Soviet period). ${ }^{44}$ 
We have a fairly good summary of Arsen'ev's views on the issue of the indigenous people in his report to the First Congress of the Physicians of Priamur region in Khabarovsk. Arsen'ev appears to have shared in the long discussion on the dying out of Siberian natives, which was going on in Russian scholarship and public debates in the second half of the nineteenth century. ${ }^{45}$ In that debate, he took the position of those who argued that indeed the native peoples of Siberia were dying out and that the outside forces were at fault. In the text of the report, Arsen'ev appeared as a dedicated evolutionist:

There are peoples who, in their development, must pass through all stages of culture from the primitive hunter to reindeer herder, then to gardening and only then to agriculture. Here ... no abrupt leaps are possible and any drastic breakup of the stadial sequence in development is deadly for the indigenes. Debauchery and its consequences, which destroy both the body and the soul, illnesses, and drunkenness are the result of the invasion into their world of the culture of the West, the culture that does not correspond to the general way of their lives. ${ }^{46}$

In Arsen'ev's mind, the natives were victims of the powerful invasion by the Russians and the Chinese. Both were equally at fault in the unfolding saga of the decline of the indigenous peoples. He listed several key factors that destroyed the native communities: the economic deprivation and exploitation, addiction to alcohol and opium (due to the Russians and the Chinese), diseases, and the psychological crisis that followed the destruction of the native life-worlds. Among the solutions proposed by Arsen'ev in his report was the provision of settled natives with land and organization of American style reservations (Arsen'ev considered the United States to be exemplary in its current treatment of native peoples) for the nomadic and semi-nomadic peoples.

Perhaps it is not surprising that following the fall of the dynasty in the spring of 1917, Arsen'ev was appointed the regional commissar for the affairs of indigenous peoples. By 1916, Arsen'ev developed a rift with his former patron Gondatti and complained about Gondatti to Anuchin and the leader of Siberian regionalists G. N. Potanin. ${ }^{47}$ Some sources suggest that vindictive Gondatti assigned Arsen'ev to a regiment that was sent to the front, and only the revolution saved the explorer from perishing in the war. Be it as it may, Arsen'ev wrote an excited letter to Potanin, sharing his plans for the work with indigenous peoples. ${ }^{48}$ Soon, however, he resigned, citing inability to achieve any results under the circumstances of war and revolution (as he wrote about 
it in 1922 to the permanent secretary of the Soviet Academy of Sciences S.F. Oldenburg). ${ }^{49}$

During the Revolution and the Civil War Arsen'ev worked for various governments supervising the fishing industry. As soon as Ian Gamarnik proclaimed the arrival of Soviet power in late 1922, Arsen'ev wrote to various academic acquaintances in the capital and reported on his work and whereabouts. He was first deprived of voting rights as a former officer but, by 1924, we see him as a candidate to represent the Far Eastern krai at the celebration of the bicentenary of the Academy of Sciences in Leningrad. He returned to work in the Khabarovsk museum and made a few expeditions. His literary works were serialized for children, and he published articles on the Far Eastern economy and ethnography in local scholarly publications. After an expedition to the lower Amur, he returned home with a cold and died from pneumonia in 1930. But his death was just the beginning of the tragedy experienced by his family.

In 1932-1934, a fake organization of Japanese spies was invented in Kamchatka by the GPU, the Soviet secret police. At the center of the intrigue was Albert Nikolaevich Lipskii, an aspiring ethnographer and agent and later officer of the GPU-NKVD. Lipskii had been at odds with Arsen'ev since 1917, accusing Arsen'ev of provincialism and lack of systematic preparation. Lipskii himself was clearly a brutal person, known for participating in executions during the Civil War and especially for his role in the suppression of various uprisings against the Soviet power. He was also responsible for the repressions of representatives of native peoples on the Amur. It appears that Lipskii construed an anti-Soviet organization in Kamchatka and posthumously appointed Arsen'ev to lead it. Arsen'ev was now proclaimed a Japanese spy and a great power chauvinist..$^{50}$ Although he could no longer be harmed, his widow, Margarita Nikolaevna (née Solov'eva) was arrested and executed. Arsen'ev's daughter also was sent to the camps and emerged from the experience psychologically destroyed. In 1935-1938, Arsen'ev's suggestion that "the Ussuri region must be Russian" was realized by Stalinist ethnic cleansing; the Chinese were expelled in 1935-1937, and the Koreans in 1938. ${ }^{51}$ The world that enabled Arsen'ev's work-the world of multiple ethnic communities-had been largely destroyed. But later decades would still produce demand for the kind of political ecology that V. K. Arsen'ev had practiced. 
Sergey Glebov received his $\mathrm{PhD}$ from Rutgers University. He is currently a research fellow at the Institute of Humanities and Social Sciences at Tyumen State University and Associate Professor of History at Smith College and Amherst College. Glebov is also a founding editor of Ab Imperio: Studies in New Imperial History and Nationalism in the Post-Soviet Space.

\section{Notes}

1. Even while Arsen'ev was proclaimed a Japanese spy, and his widow and daughter arrested, his books continued to be published both in the center and in the Far East. For an overview of Arsen'ev's publications, see V. Pak, ed., V. K. Arsen'ev, 1872-1830 gg.: Bibliograficheskii ukazatel' (V. K. Arsen'ev, 1872-1830: Bibliographic Guide) (Vladivostok: Valentin, 2018). It should be noted that the bibliographic guide includes over 200 pages of works by and about Arsen'ev.

2. Oksana Sarkisova, Screening Soviet Nationalities: Kulturfilms from the Far North to Central Asia (London; New York: I. B. Tauris, 2017), 83-90.

3. Michael Kaminsky, "Under the Influence of Akira Kurosawa: The Visual Style of George Lucas," in Myth, Media, and Culture in Star Wars: An Anthology, ed. Douglas Brode and Leah Deyneka (Lanham: Scarecrow Press, 2012), 88.

4. Rossiiskii Gosudarstvennyi Arkhiv Literatury i Iskusstva (RGALI), F. 2020, Op. 1, D. 115, Ll. 11-12.

5. See David Bell et al., eds., Political Ecology: Global and Local (London: Routledge, 2005), 1.

6. Richard Wortman, "Russian Noble Officers and the Ethos of Exploration," Russian History/Histoire russe 35, nos. 1-2 (Spring-Summer 2008): 181-197.

7. For a discussion of the concept of imperial situation, see Ilya Gerasimov, Sergey Glebov, and Marina Mogilner, "Hybridity: Marrism and the Problems of Language of the Imperial Situation," Ab Imperio Vol. 16, no. 1 (May 25, 2016): 27-68, esp. 27-28.

8. For the argument about empires as producers of difference, see Jane Burbank and Frederick Cooper, Empires in World History: Power and the Politics of Difference (Princeton: Princeton University Press, 2011).

9. Here and below biographical information is from Posluzhnoi spisok podpolkovnika V. K. Arsen'eva, RGIA DV, F. 4412, Op. 1, Ll. 17-24.

10. Priamur krai was an administrative unit in imperial Russia established in 1884. It consisted of the Amur province along the middle flow of the river and the Maritime province, which stretched from the border with Korea and the Qing Empire in the south to Chukotka in the north. In certain periods, the Priamur krai also included the Sakhalin island and the Transbaikal province. The administrative capital of the unit was in Khabarovka (later Khabarovsk), where the governor general resided. 
11. For a study of the Russian military's engagement with Asia, see Alex Marshall, The Russian General Staff and Asia, 1860-1917 (London; New York: Routledge, 2006). For an intriguing discussion of "Russian military culture" as an anthropological problem, see V. K. Arsen'ev, Sobranie sochinenii v 6 tomakh (Vladivostok: Rubezh, 2012), 3:16-18.

12. V. K. Arsen'ev, Zhizn' i prikliucheniia v taige (Moscow: Geografgiz, 1957); V. K. Arsen'ev, Kritiko-biograficheskii ocherk (Moscow: Detgiz, 1956).

13. For a thorough study of the evolution of the Russian involvement in the Far East, see Igor Lukoianov, "Ne otstat' ot derzhav . . .": Rossiia na Dal'nem Vostoke $v$ kontse XIX-nachale XX vv. (St. Petersburg: Nestor-Istoriia, 2008).

14. P. F. Unterberger, "Priamurskii krai, 1906-1910," in Zapiski Russkogo Imperatorskogo Geogrficheskogo Obshchestva po otdeleniiu statistiki 12 (1912), 50.

15. Terms like "yellow question" and yellow peril began to circulate in the Russian Far East in the late 1880s, gaining momentum by the time of the Boxer Rebellion.

16. Unterberger, "Priamurskii krai," 52-53.

17. B. F. Adler, an ethnographer, followed the more traditional anthropogeographic approach rather than the new racial science of anthropology. See Marina Mogilner, Homo Imperii: A History of Physical Anthropology in Russia (Lincoln: University of Nebraska Press, 2013), 67.

18. On Shternberg, see Sergei Kan, Lev Shternberg: Anthropologist, Russian Socialist, Jewish Activist (Lincoln: University of Nebraska Press, 2009).

19. Fridtjof Nansen, Through Siberia, the Land of the Future, trans. Arthur G. Chater (New York: Frederick A. Stokes, 1914), 347-348.

20. Arkhiv Khabarovskogo kraevogo muzeia im. N. I. Grodekova (AKhKM), F. 53,. Op. 11, D. 46, Ll. 12, 20. On Vovk, see Marina Mogilner, Homo imperii, 93-95.

21. On ethnography and political exiles, see Sergey Glebov, "Siberian Ruptures: Dilemmas of Ethnography in Imperial Situation," in An Empire of Others: Creating Ethnographic Knowledge in Imperial Russia and the USSR, ed. Roland Cwetkowski and Alexis Hofmeister (Budapest: Central European University Press, 2013), 271-310. See also an excellent biography of the archetypical and influential exile-ethnographer O. Milevskii, A. Panchenko. "Bespokoinyi Klements": Opyt intellektual'noi biografii (Moscow: ROSSPEN, 2017).

22. Viacheslav Ogryzko, Severovedy Rossii: Materialy k biograficheskomu slovariu (Moscow: Literaturnaia Rossiia, 2007), 35, 131-132; On Gondatti's contribution to Yupik ethnography, see Igor Krupnik and Michael Chlenov, Yupik Transitions: Change and Survival at Bering Strait, 1900-1960 (Fairbanks: University of Alaska Press, 2013), 20-21.

23. See Abraham Ascher, P. A. Stolypin: The Search for Stability in Late Imperial Russia (Stanford: Stanford University Press, 2002); Abraham Ascher, The Revolution of 1905: Authority Restored (Stanford: Stanford University Press, 1994); George Levings Yaney, The Imperial Russian Government and the Stolypin Land Reform (Ann Arbor: University Microfilms, 1970). 
24. A. A. Tatishchev, Zemlia i liudi. V gushche pereselencheskogo dvizheniia (Moscow: Russkii put', 2001), 111.

25. Viktoriia Romanova, Vlast' i evrei na Dal'nem Vostoke Rossii: Istoriia vzaimootnoshenii (vtoraia polovina XIX-20-e gody 20-go v.), Evreiskie Obshchiny Sibiri i Dal'nego Vostoka, VII (Krasnoiarsk: Institut sotsial'nykh i obshchinnykh rabotnikov Sibiri i Dal'nego Vostoka, 2001), 81-122.

26. The only monograph, albeit hagiographic in tone, on Gondatti is N. I. Dubinina, Priamurskii general-gubernator N.L. Gondatti (Khabarovsk: Priamurskoe geogr. ob-vo, 1997).

27. On colonization, see Kolonizatsiia Sibiri v sviazi s obshchim pereselencheskim voprosom (St. Petersburg: Committee of the Siberian Railroad, 1900). For an overview of Russian colonization policies, see Willard Sunderland, “The 'Colonization Question': Visions of Colonization in Late Imperial Russia," Jahrbücher Für Geschichte Osteuropas, Neue Folge, 48, no. 2 (January 1, 2000): 210-232. See also Nicholas Breyfogle, Abby Schrader, and Willard Sunderland, Peopling the Russian Periphery: Borderland Colonization in Eurasian History (New York: Routledge, 2007).

28. On the Resettlement Administration, see Peter Holquist, "'In Accord with State Interests and the People's Wishes': The Technocratic Ideology of Imperial Russia's Resettlement Administration," Slavic Review 69, no. 1 (2010): 151-179; Willard Sunderland, "The Ministry of Asiatic Russia: The Colonial Office That Never Was but Might Have Been," Slavic Review 69, no. 1 (2010): 120-150.

29. T. I. Polner, Zhiznennyi put' kniazia Georgiia Evgen'evicha L'vova (Moscow: Russkii put', 2001), 201-208.

30. David A. J. Macey, "Agricultural Reform and Political Change: The Case of Stolypin," in Reform in Modern Russian History: Progress Or Cycle?, ed. Theodore Taranovski and Peggy McInerny (Cambridge University Press, 1995). p. 168.

31. Russian State Historical Archive of the Far East (Further RGIA DV), F. 702, Op. 1, D. 716, 1. 6.

32. Ibid. L. 137.

33. These expeditions are described but very selectively and hagiographically by N. I. Egorchev, Neizvestnyi Arsen'ev (Voladivostok: DVGU, 2016) and "Soglasno lichnogo prikazaniia Vashego Prevoskhoditel'stva . . ." (Vladivostok: DVGU, 2014).

34. Fanza is a Russian corruption of Chinese fangzi, house, and was used in the region to refer to Chinese type dwellings.

35. Sekretnaia instruktsiia general-gubernatora Gondatti shtabs-kapitanu Arsen'evu, RGIA DV, F. 702, Op. 1, D. 716, Ll. 144-148.

36. Doklad V. K. Arsen'eva N. L. Gondatti, RGIA DV, F. 702, Op. 1, D. 716, L. $130 \mathrm{ob}$.

37. On the anxiety about Russians as colonizers, see A. Remnev and N. Suvorova. "'Russkoe delo' na aziatskikh okrainakh: 'russkost" pod ugrozoi ili 'somnitel'nye kul'turtregery,'” Ab Imperio 8, no. 2 (2008): 157-222. 
38. RGIA DV, F. 702, Op. 1, D. 716, L1. 20 and 35.

39. V. K. Arsen'ev, “Kratkii voenno-geograficheskii i voenno-istoricheskii ocherk ussuriiskogo kraia, 1901-1911," in Sobranie sochinenii, 3: 218.

40. Arsen'ev, “Kratkii voenno-geograficheskii," 202.

41. Letter of V. K. Arsen'ev to F. F. Aristov, July 30, 1930, AKhKM, F. 53, Op. 11, D. 14, L1. 22 and 33.

42. The term "inorodets" had both a legal and a common meaning. Legally, inorodtsy were a separate estate governed under the 1822 Statute on Inorodtsy developed by M. Speransky. In common parlance, the term could be applied narrowly to indigenous peoples of Siberia, or to any group of non-Slavic origin. See John W. Slocum, "Who, and When, Were the Inorodtsy? The Evolution of the Category of 'Aliens' in Imperial Russia," Russian Review 57, no. 2 (April 1, 1998): 173-190.

43. On the introduction of the statute, see Marc Raeff, Siberia and the Reforms of 1822 (Seattle: University of Washington Press, 1956). On the smaller peoples of Siberia, see Yuri Slezkine, Arctic Mirrors: Russia and the Small Peoples of the North (Ithaca: Cornell University Press, 1996); James Forsyth, A History of the Peoples of Siberia: Russia's North Asian Colony 1581-1990 (Cambridge: Cambridge University Press, 1994).

44. RGIA DV, F. 702, Op. 5, D. 109, Ll. 5-92.

45. On the debate, see Glebov, "Siberian Ruptures," in An Empire of Others, ed. Cwetkowski and Hofmeister.

46. V. K. Arsen'ev, "Vymiranie inorodtsev Amurskogo kraia," in Sobranie sochinenii, 3:517-518.

47. AKhKM, F. 53. Op. 11. D. 14, Ll. 5-6, 28.

48. AKhKM, F. 53, Op. 11, D. 46, L. 58ob.

49. AKhKM, F. 53, Op. 11, D. 46, L. 22.

50. S. Vainshtein, “Romantika i tragedii v sud'be A. N. Lipskogo," in D. D. Tumarkin, Repressirovannye Etnografy. (Moscow: Vostochnaia literatura, 2003), 455-492.

51. For a discussion of Stalinist deportations in the Far East, see Elena Chernolutskaia, Prinuditel'nye migratsii na sovetskom Dal'nem Vostoke v 1920-e - 1950-e gg. (Vladivostok: Dal'nauka, 2011). For an argument about Arsen'ev's role in creating the climate for deportations, see Jon K. Chang, Burnt by the Sun: The Koreans of the Russian Far East (Honolulu: University of Hawai'i Press, 2016). 